\title{
Imágenes-agenciamientos y conceptos-acontecimientos en la traducción narrativa*
}

\author{
Images-assemblage and concepts-events \\ in narrative translation
}

Imagens-agenciamentos e conceitos-acontecimentos na tradução narrativa

Fecha de entrega: 12 de septiembre de 2016

Fecha de evaluación: 10 de diciembre de 2016

Fecha de aceptación: 25 de enero de 2017

Carolina Villada Castro ${ }^{* *}$

\section{Resumen}

Este artículo, centrado en el tema de la traducción narrativa, presenta un análisis de las imágenes-agenciamiento en la Nueva Corónica y Buen Gobierno (1615) de Felipe Guamán Poma de Ayala y el estudio de los conceptos-acontecimientos en A queda do céu, palavras de um xamã Yanomami de Kopenawa y Albert (2015). Con el objetivo

* El presente texto es un avance de la investigación que la autora realiza sobre la traducción y la sitematización de experieincias. DOI:http://dx.doi.org/10.15332/s0120-8462.2017.0116.08

** Profesional en Filosofía de la Universidad de Antioquia, Colombia. Desarrolló su trabajo de grado sobre Ricoeur: variaciones en torno a la subjetividad, bajo la dirección de Luz Gloria Cárdenas Mejia. Defendió disertación de maestría en Estudios de la Traducción en la Universidad de Florianópolis, en el estado de Santa Catarina, Brasil, UFSC-PGET. Correo electrónico: carolina.villadacastro@gmail.com 
de indicar el potencial conceptual, poético y cosmopolítico de la traducción nativa, se tiene en cuanta la importancia de su traducción en la época colonial peruana y en la contemponaneidad viene considerados desde Guamán Poma y Yanomami Kopenawa, según imágenes y conceptos tanto de agencia como de acontecimiento.

Palabras clave: filosofía amerindia, traducción nativa, Guamán Poma, Kopenawa.

\section{Abstract}

This article, focused on the subject of narrative translation, presents an analysis of images-assemblage in the New Chronicle and Good Government (1615) by Felipe Guamán Poma de Ayala and the study of the concepts-events in A queda do céu, palavras de um xamã Yanomami by Kopenawa and Albert (2015). In order to indicate the conceptual, poetic and cosmopolitical potential of the native translation, the importance of its translation in the Peruvian colonial period is taken into account and in contemporaneity are considered from Guamán Poma and Yanomami Kopenawa, according to images and concepts both of assemblage and event,

Keywords: Amerindian philosophy, native translation, Guamán Poma, Kopenawa. 


\section{Resumo}

Este artigo, focado no tema da tradução narrativa, apresenta uma análise das imagens-agenciamento na Nueva Corónica y Buen Gobierno (1615) do Felipe Guamán Poma de Ayala e o estudo dos conceitos-acontecimentos em A queda do céu, palavras de um xamã Yanomami de Kopenawa y Albert (2015). Com o objetivo de indicar o potencial conceitual, poético e cosmopolítico da tradução nativa, se tem em conta a importância da sua tradução na época colonial peruana e na contemporaneidade vem considerados desde Guamán Poma y Yanomami Kopenawa, segundo imagens e conceitos tanto de agência como de acontecimento.

Palavras-chave: filosofia ameríndia, tradução nativa, Guamán Poma, Kopenawa. 


\section{Introducción}

A partir de las imágenes que acompañan la Nueva Corónica y Buen Gobierno (1615) de Guamán Poma de Ayala en el siglo XVII ${ }^{1}$ y del texto escrito a dos manos A queda do céu, palavras de um xamã Yanomami (2015) -sin traducción aún al españolpor Kopenawa y Albert del actual siglo XXI ${ }^{2}$, proponemos indagar por el potencial filosófico y poético de estas traducciones nativas interpelando nuestra mitología blanca -recordando la aguda interrogación filosófica de Derrida (1971) - e instigando nuevos modos de pensar. En este contexto, la traducción nativa se afirma como una característica singular del pensamiento nativo, no solo debido a las experiencias de contacto con el mundo blanco; sino como característica singular al ethos de este pensamiento, pues aquí pensar siempre es una actividad que acontece con otros $y$ entre otros, así las filosofías amerindias inevitablemente son filosofías de la alteridad ${ }^{3}$. Ahora bien, como veremos, en este caso el otro no es solamente el blanco, pues la condición de alteridad es compartida tanto por otros pueblos, otros amerindios, así como por los no-humanos (animales, ancestros, muertos, entre otros). De tal modo que las filosofías amerindias socavan el antropocentrismo moderno de la filosofía occidental, para afirmar un pensamiento de la alteridad en una mirada cosmopolítica ${ }^{4}$.

En esta perspectiva nativa, pensar y traducir acontecen de modo inseparable, pues este pensamiento se despliega entre mundos: las etnias andinas de Guamán Poma o entre humanos y no-humanos durante los encuentros chamánicos Yanomamni. Sin embargo, como intentaremos detallar a partir del análisis semiótico de los dibujos

1 Acceso al texto y dibujos en: $h$ ttp://www.kb.dk/permalink/2006/poma/titlepage/es/text/?open=id3083608

2 La edición más reciente en portugués A queda do céu. Palavras de um xamã Yanomami. Tradução de Beatriz Perrone-Moisés, prefácio de Eduardo Viveiros de Castro. São Paulo: Companhia das Letras. La primera versión fue en francés: Kopenawa, D. Ct Albert, B., 2010. La chute du ciel. Paroles d'un chaman Yanomani, préface de Jean Malaurie. Paris: Plon. Posteriormente fue traducido al inglés: Kopenawa, D. \& Albert, B., 2013. The falling sky: Words of a Yanomami shaman. N. Elliot \& A. Dundy (Trads.). Massachusets-London: Belknap Press. Aún por traducirse al español.

3 Sobre este asunto son imprescindibles los trabajos del antropólogo Eduardo Viveiros de Castro: A inconstância da alma selvagem (2002). Paulo Neves (Trad.). São Paulo: COSACNAIFY. Y, As metafísicas canibais (2015). São Paulo: COSACNAIFY; con versión en español: Metafísicas canibales. Líneas de antropología postestructura (2010). Stella Mastrangelo (Trad.). Buenos Aires: Katz editores.

4 En el contexto de las discusiones contemporáneas se destacan además de A queda do céu (Kopenawa y Albert, 2015), en cuanto traducción nativa y texto ejemplar de la antropología de los otros; los trabajos paralelos de Viveiros de Castro y Danowski (2014): Ha mundo por vir?: ensaio sobre os medos e os fins, Cultura e Barbarie: Instituto socioambiental. 
de Guamán Poma y de los conceptos de Kopenawa, imágenes y conceptos nativos implican al mismo tiempo acontecimientos y agenciamientos (cosmo) políticos.

Para esto, en un primer momento vamos a analizar el texto visual que acompaña la crónica de Guamán Poma (1980 a), a partir del análisis de una pequeña selección de dibujos del autor, a fin de indicar el modo como la producción de cada imagen y la relación que emerge entre ellas agencian una traducción nativa crítica. Seguidamente, trabajaremos los conceptos-acontecimientos de Kopenawa en A queda do céu (2015), bruma de metal (fumaça de metal), oro caníbal (ouro canibal), urihi (tierra-selva) y cosmopolítica, conceptos que traducen el pensamiento Yanomami e interpelan nuestro lenguaje conceptual occidental. Finalmente, proponemos una serie de apuntes sobre las singularidades de la traducción nativa desde el intervalo histórico entre Guamán Poma y Kopenawa.

\section{Imágenes-agenciamiento}

La Nueva Corónica y Buen gobierno (1615), el manuscrito del nativo peruano Guamán Poma de Ayala, es una expresión de la traducción nativa en el texto escrito donde se agencia un complejo enunciativo plural y subversivo en el que reverberan el quechua, el aimara entre otras lenguas nativas (Urioste, 1987, p. XXXI), que transformaron fonológica, lexicográfica y sintácticamente el español, hasta considerarse un ejemplar de la variante andina del español ineludible. Sin embargo, el potencial de la obra de Guamán Poma de Ayala consiste en la traducción del pensamiento de las diversas etnias andinas sobre la ilegitimidad de la conquista y su voluntad de autonomía. Aquí emerge un discurso nativo que perfora la lengua del colonizador para desestabilizar además de su estructura lingüística, su lenguaje conceptual y cultural. En suma, una subversión de la lengua que agencia una enunciación plural (Quispe, 2004, p. 248): "Soy todos bosotros" (F. 964), he ahí la voz múltiple de este agente amerindio que torna la escritura además de memoria y testimonio, un espacio de forcejeo de sentidos y fuerzas entre mundos culturales irreducibles.

No obstante, lo que intentaremos focalizar no es el texto verbal, sino el texto visual que acompaña la Nueva Corónica y Buen Gobierno (1615), esto es, la traducción nativa que opera en los dibujos de Guamán Poma, a través del análisis semiótico de una pequeña muestra de sus dibujos -entre los 398 dibujos que acompañan la crónica-. Para comenzar, es importante indicar que la semiótica, a diferencia de la iconología, 
no refiere las imágenes como representaciones, sino como signos visuales autónomos (López, 1988). Por tanto, el texto visual de Guamán Poma no es una representación del texto verbal, limitándose a una función ilustrativa y subordinada; al contrario, el texto visual es paralelo y autónomo respecto del texto verbal. De este modo, lo que proponemos es presentar los dibujos como un campo semiótico autónomo, donde la traducción acontece a partir de los signos culturales heterogéneos que componen cada imagen y las relaciones que acontecen entre ellos: yuxtaposiciones, ligaciones o disyunciones. En esta perspectiva, en el texto On pictorial language and the typology of culture in a New World chronicle, Rolena Adorno (1981) destaca la función metalingüística y metacrítica del elemento visual (p. 101), lo que nos permitirá indicar que en los dibujos de Guamán Poma las imágenes operan agenciamientos mientras traducen, es decir, codifican y descodifican los signos culturales andinos y no-andinos (Adorno, 1981), para denunciar la ilegitimidad de la conquista y del proceso de colonización.

De este modo, el texto visual es un campo semiótico en tensión, desdobla relaciones tanto de contacto como de conflicto, la búsqueda de supuestas "equivalencias culturales" es apenas provisional y estratégica, en el caso de la primera figura a referir, el objetivo es indicar continuidades entre los relatos históricos y religiosos entre europeos y andinos, a partir de la historia de un pueblo subordinado por un gran imperio en busca de libertad, tanto en el caso del pueblo de David como de los pueblos andinos subordinados por el imperio Inca, pues a lo que se apunta es a su necesidad de liberación:

Figura 1. Liberación
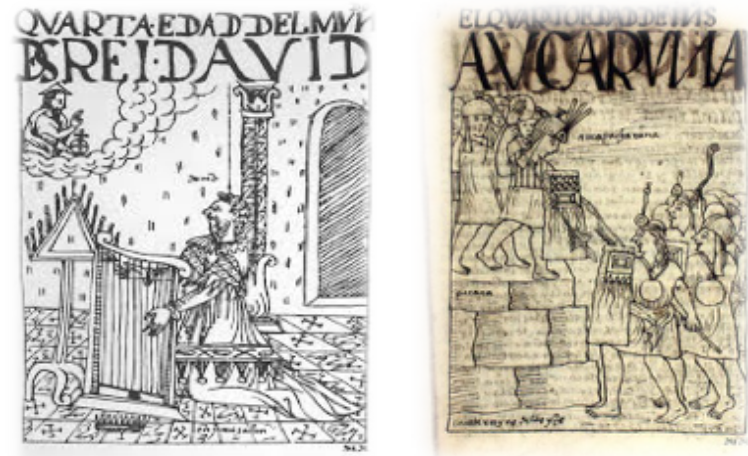

Fuente: tomado de http://www.kb.dk/permalink/2006/poma/titlepage/es text/?open=id3083608 
Sin embargo, esta tentativa de codificación va transformándose después al construir una narrativa histórica de la mirada nativa. Poco a poco este campo semiótico comienza a indicar las tensiones y la agencia amerindia en los momentos históricos que focaliza la imagen. He ahí el caso de la siguiente figura, al relatar el momento de la conquista y de la muerte de Atahualpa y, como puede instigarse, el momento de la mudanza de imperio para los pueblos andinos:

Figura 2. Muerte de Atahualpa
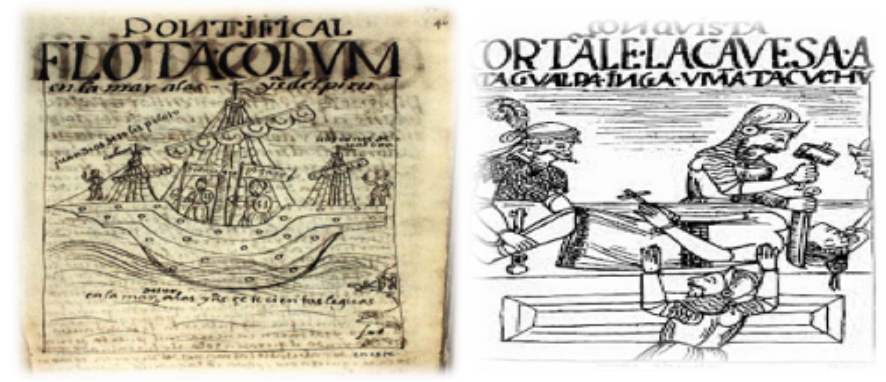

Fuente: tomado de http://www.kb.dk/permalink/2006/poma/titlepage/es/text/?open=id3083608

Aquí comienza un dislocamento de la codificación a la denuncia que va a intensificarse poco a poco. Así, la siguiente figura que describe las funciones de los corregidores entre los pueblos andinos, indica también los límites y las fronteras culturales entre europeos y andinos, en síntesis, las tensiones que produce este encuentro entre mundos. Lo que va a ocasionar que de la búsqueda de codificación se pase a una descodificación continua, destacando las diferencias, los mundos irreducibles y los abusos ilegítimos:

Figura 3. Castigo

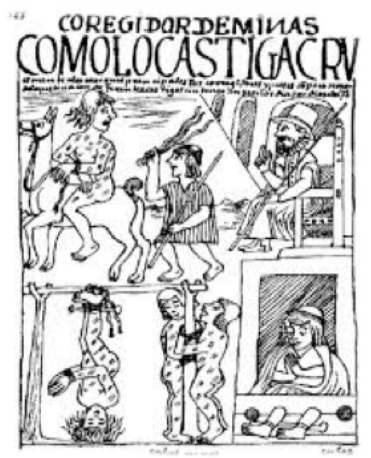

Fuente: tomado de http://www.kb.dk/permalink/2006/poma/titlepage/es/text/?open=id3083608 
En ese caso la figura agencia una crítica del nuevo sistema colonial que somete a los pueblos andinos. En el pasaje entre estas figuras y, más aún, en la serie de 398 dibujos de Guamán Poma, que aquí apenas referimos a través de una muestra ínfima, podemos percibir lo que Rolena Adorno (1981) denomina una typology of culture, es decir, el modo como este campo de imágenes hechas a base de signos culturales heterogéneos cruzados establecen diferencias y tensiones entre el mundo interno andino y el mundo externo europeo. De tal modo que se pasa de las continuidades y proximidades a los límites y fronteras irreducibles entre las culturas. He ahí el plano de las relaciones entre traducción y semiótica cultural, en este caso la producción de imágenes es un acto de traducción nativa, esto es, el campo de imágenes es un espacio vivo de sentidos y forcejeos. No en vano, ahora disponemos la última figura que queremos tratar: la ciudad del infierno.

Figura 4. La ciudad del infierno
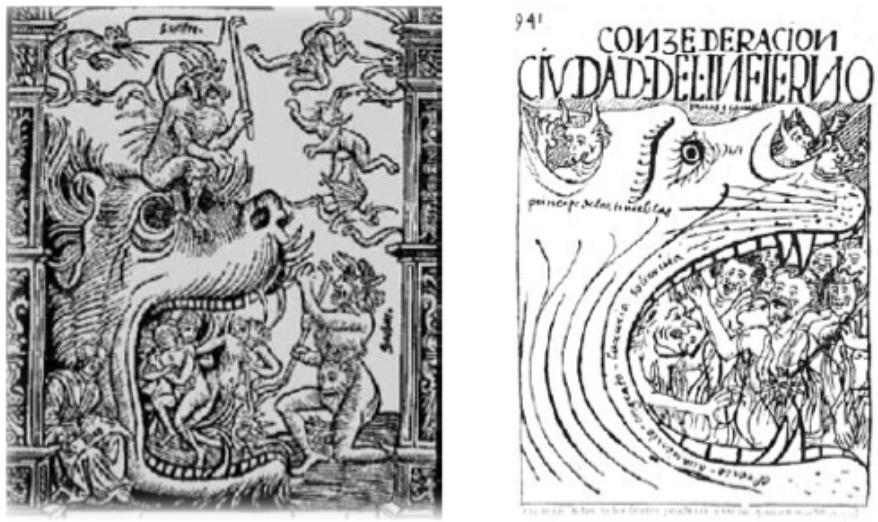

Fuente: tomado de http://www.kb.dk/permalink/2006/poma/titlepage/es/text/?open=id3083608

Aquí contrastamos una de las ilustraciones medievales europeas de la boca del infierno -izquierda- con la imagen andina de Guamán Poma de la ciudad del inferno -a la derecha-, con el objetivo de indicar su acto transcodificador, ya que esta figura además de actuar concretiza la agitación de la sociedad colonial. Dicha figura logra un potencial performativo, pues forcejea $\mathrm{y}$, al mismo tiempo, produce su gesto subversivo.

Este movimiento del lenguaje de las imágenes de la codificación a la transcodificación o de las continuidades a las discontinuidades y fronteras culturales describe la andinización del signo (Adorno, 1981, p. 97), esto es, el uso estratégico de la imagen para la 
denuncia, la experiencia policultural que recorre cada imagen andina (Adorno, 1980, p. 104) y su agenciamiento poético y político. En este primer abordaje, los dibujos de Guamán Poma nos permiten entonces indicar la traducción nativa con un acto de descodificación y transcodificación cultural, tal como opera en la imagen andina. Pero esa transformación no lleva a una fusión o mezcla pasiva en el mestizaje; al contrario, indica una afirmación de la diferencia cultural y una búsqueda de autonomía, que permite apuntar que la traducción siempre acontece entre inconmensurables culturales que alteran los términos en relación. Así, la discontinuidad entre la cultura europea y la cultura andina tan viva siempre, instigan a reiterar la actualidad de la traducción de las imágenes andinas de Guamán Poma y la pertinencia de su enunciación plural aun en nuestros días.

\section{Conceptos-acontecimientos}

Otra contribución por analizar remite a A queda do céu, palavras de um xamã Yanomami (2015), específicamente, a los conceptos-acontecimientos chamánicos: bruma de metal (fumaça de metal), oro caníbal (ouro canibal), urihi (tierra-selva) y cosmopolítica. El objetivo es detallar el modo como estos conceptos operan como traducciones nativas con importantes consecuencias antropológicas, pues "el blanco se torna aquí objeto de otras antropologías" (Albert, 2002a, p. 10). Así como sus consecuencias políticas, ya que la problematización de los "mitos de los blancos" (Abert, 2002, p. 4) y su "monolingüismo cosmológico" (Viveiros de Castro, 2015, pp. 27-28) es básica para cuestionar la función política que reproducen, en los términos de Albert el problema consiste en la "auto-objetivación indígena en las categorías blancas de etnización: reproducción del discurso y funciones de poder de los blancos por los indígenas" (2002b, p. 4).

Para comenzar es necesario indicar que la traducción nativa chamánica no refiere a una primera persona, ni queda limitada a la función-autor, ella siempre es habla de los otros o palabras dadas, una multitud reverbera tornando la palabra-canto chamánico en polifonía y polilogia, al respecto indica para nosotros Kopenawa (2015):

As palavras dos xapiri estão gravadas no meu pensamento, no mais fundo de mim. São as palavras de Omama. São muito antigas, mas os xamãs as renovam o tempo todo. Desde sempre, elas vêm protegendo a floresta e seus habitantes. Agora é minha vez de possuí-las. Mais tarde, elas entrarão na mente de meus 
filhos e genros, e depois, na dos filhos e genros deles. Então será a vez deles de fazê-las novas. Isso vai continuar pelos tempos afora, para sempre. Dessa forma, elas jamais desaparecerão. Ficarão sempre no nosso pensamento (pp. 65-66).

Las palabras de los xapiri están grabadas en mi pensamiento, en lo más hondo de mí. Son palabras de Omama. Son muy antiguas, pero los chamanes las renuevan todo el tiempo. Desde siempre, ellas vienen protegiendo la selva y sus habitantes. Ahora es mi oportunidad de poseerlas. Pero más tarde, entrarán en la mente de mis hijos y yernos, y después, en los hijos y yernos de ellos. Entonces será el momento de ellos renovarlas. Esto va a continuar a lo largo de los tiempos, para siempre. De esta forma, ellas nunca desparecerán. Quedarán siempre en nuestro pensamiento (traducción propuesta).

Precisamente, tener chamán ${ }^{5}$ consiste en una tarea de traducción inevitable para el chamán como pasador entre mundos, en el caso de Kopenawa, como chamán Yanomami que invoca el canto de los xapiri tanto para compartir con su pueblo la sabiduría de la selva como para hablar e interpelar a los blancos. El pensamiento chamánico es así un pensamiento que acontece entre la multitud de otros humanos y no-humanos, en los términos de Albert (2015) el chamanismo implica la traducción de un polilogos intercultural (p. 540) y, así, la exigencia permanente e inminente consiste en "produzir um pensamento que articulasse os dois mundos entre os quais ele transitava sem cessar" (producir un pensamiento que articulará los dos mundos entre los cuales transitaba sin cesar) (Kopenawa, 2015, p. 528) (traducción propuesta).

Este polilogos, o para usar la bella imagen de Kopenawa (2015), este "pensamento em todas as direções" (pensamiento en todas las direcciones) (p. 466) cruza geografías y yuxtapone tiempos, acoge el pensamiento de otros ameríndios, los caminos lejanos del pasado del pueblo Yanomami y alimenta con sus caminos por venir, así estos pensamientos "podem crescer, caminhar e se multiplicar ao longe, em todas as direções" (pueden crecer, caminar y multiplicarse a lo lejos, en todas las direcciones) (p. 510). El umbral de este camino de traducción corresponde al comienzo de la iniciación

5 Tener chamán esta expresión indica el chamanismo como un aprendizaje que se trabaja colectivamente con otros chamanes y que se alimenta con la práctica continua a lo largo de la vida del iniciado, además, como precisa Viveiros de Castro (2006) tener-chamán (ter-xamã) concierne a un funcionamiento básico en los modos de socialidad de varios pueblos amerindios, pues el chamán es quien mantiene viva las relaciones entre humanos y no-humanos (animales, ancestros, muertos), es decir, compone un continuo social entre próximos y lejanos, tan vital para la sobrevivencia de sus pueblos. 
chamánica (Lizot, 1988), la salida fuera de sí que prepara un devenir-otro(s) inagotable que ha de transitar el iniciado. Pues este pasaje al exterior opera una apertura de la escucha del chamán, en adelante, aprendiz de los cantos de los xapiri y de la lengua del sueño en compañía de los otros chamanes ${ }^{6}$. En estos largos trayectos brotan las imágenes-conceptos chamánicos que implicaron el soplo de vida de la yãkoana ${ }^{7}$, que Kelly y Mimica describen en los siguientes términos: "Refrações intermináveis de imagens e dimensionalidades variáveis, estas são as implicações com o infinito dos xamãs Yanomami, para usar a expressão de Mimica” (Kelly, 2013, p. 180) ${ }^{8}$.

Sin embargo, estas imágenes-conceptos se construyen tanto a partir de la escucha de los xapiri como de las experiencias de contacto con otros ameríndios y con los blancos, así como nos indicara Albert (1992), ellas tienen una fuerza cosmológica y una historicidad que se mantienen viva en el presente de su resistencia. Es por esto que proponemos estas imágenes-conceptos chamánicos como conceptos-acontecimientos, ya que problematizan paralelamente las constelaciones conceptuales de los blancos y sus modos de vivir, de tal manera que proponen otros modos de pensar las alteridades, los modos de socialidad y la sabiduría de la selva con implicaciones éticas y políticas inminentes, tal como intentaremos esbozar en los conceptos de bruma de metal (fumaça de metal), oro caníbal (ouro canibal), urihi (tierra-selva) y cosmopolítica.

6 Xapiri agentes no-humanos, también denominados "espíritus" amazónicos (Viveiros de Castro, 2006), evitamos el uso del término "espíritu" no solo porque mantiene los ecos de la metafísica occidental tan diversa al pensamiento Yanomami; sino para insistir en el carácter cosmopolítico de los otros en este contexto. El aprendizaje del chamán es entonces un aprendizaje de la escucha, del canto de los xapiris, sabiduria de la selva básica para la sobrevivencia de los Yanomami.

7 Yãkoana para definirlo en los términos de Kopenawa es soplo de vida, ella revela la "voz de los xapiri". (Kopenawa y Albert, 2015, p. 84). El soplo de polvo de yõkoana de un chamán más viejo al iniciado es básica en el aprendizaje chamánico, en el transcurso del aprendizaje chamánico el iniciado poco a poco va aprendiendo a usarla, a escuchar los cantos de los xapiri y a responderles. Yãkoana no solo es soplo de vida porque permite acceder a ese canto de los otros lejanos (animales, ancestros, muertos...) que enseñan la sobrevivencia en la selva, sino que permite que ese canto perviva y se alimente con nuevos rumbos entre el pueblo Yanomami.

8 Refracciones interminables de imágenes y dimensiones variables, estas son las "implicaciones con el infinito" de los chamanes Yanomami, para usar la expresión de Mimica (1988) (citado por Kelly, 1988, p. 180). (traducción propuesta).

9 N. del T. Bruma de metal (fumaça de metal), oro canibal (ouro canibal), urihi (tierra-selva) traducciones que proponemos al español. En el primer caso bruma de metal (fumaça de metal), fumaça que puede traducirse literalmente por humo, humareda, fumarada para describir tanto los efectos de la industrialización y los objetivos desarrollistas y de progreso de la economía política occidental, que se abre paso a partir del genocidio y el etnocidio, nuestra elección es bruma de metal, para enfatizar en esa obnubilación que esta racionalidad económica moderna mantiene, pues es una de las invenciones 
Bruma de metal (fumaça de metal) es un concepto nativo cosmológico, histórico y crítico (Abert, 1992) del pensamiento Yanomami al mito blanco y etnocéntrico del universalismo cultural, recorriendo tanto los enunciados y las prácticas comunes a los misioneros, al Estado y a la ciencia. Igualmente, la fuerza de este concepto está en traducir un relato cosmo-histórico del inicio de un intercambio etnocida, que reitera la incomensurabilidad entre el antropocentrismo de la cultura occidental con el pensamiento cosmopolítico Yanomami. Aquí la articulación entre la bruma de metal (fumaça de metal) y las epidemias (Kopenawa y Albert, 2015) describe eficazmente las muertes masivas que produjeron las enfermedades de los misioneros, los proyectos mineros y los proyectos desarrollistas en la región. Como relata Kopenawa (2015): "Certo dia, as máquinas chegaram à floresta sem que nenhuma palavra as tivesse precedido. Então, nossos grandes homens, mantidos na ignorância, não se mostraram hostis com os brancos da estrada" (cierto día llegaron las máquinas a la selva sin que ninguna palabra las hubiera precedido. Entonces, nuestros grandes hombres, mantenidos en la ignorancia, no se mostraron hostiles con los blancos) (p. 306) (traducción propuesta), así, ante esa ausencia de traducción que, al mismo tiempo, niega a su interlocutor, la bruma de metal (fumaça de metal) como concepto nativo es una traducción con gran fuerza política indicando la "resistencia simbólica Yanomami" (Albert, 1992, p. 184), al devolver la voz a los interlocutores directos Yanomami y, también, al interpelar el accionar destructivo de los blancos, cuyo pensamiento está tan lleno de olvido que ignora la caída del cielo (A queda do céu) y, así, su desaparecimiento. La caída del cielo ( $A$ queda do céu) es la imagen Yanomami que expresa la desaparición de la selva paralela a la desaparición de los chamanes y sus pueblos, una exhortación crítica a problematizar el antropocentrismo a la base de la economía política occidental ecocida.

Otro de los conceptos-acontecimentos es oro caníbal (ouro canibal), la fuerza de este concepto consiste en remover las bases antropocéntricas de la economía política occidental tanto capitalista como del materialismo histórico dialéctico marxista,

culturales más sedimentadas en occidente pese a sus efectos genocidas y ecocidas; mantenemos el término en portugués en paréntesis para que el lector pueda contrastar. En el segundo caso, oro caníbal (ouro canibal), la imagen se mantiene intacta entre el portugués y el español, además de indicar una historia compartida entre nuestros pueblos nativos. Finalmente, urihi (tierra- selva) se mantiene como término nativo Yanomami, la traducción en paréntesis es para especificar la concepción de la tierra Yanomami a partir de la selva, con su carácter cosmopolítico, como alteridad vital para los Yanomami, condición de vida de su pueblo, de otros amerindios y de los blancos mismos, a fin de distinguirla de la concepción occidental de tierra-propiedad. 
pues ambos sustentan una reificación e instrumentalización de la naturaleza, basada en la metafísica moderna, según la cual la naturaleza es objeto del sujeto que puede representársela, dominarla y transformarla. No en vano, Kopenawa (2015) habla de los mineros como comedores da terra (devoradores de la tierra) (p. 334) o de la paixão pelas mercadorias (pasión por las mercancías) de los blancos (p.406), con una mirada más aguda que la marxista, Kopenawa apunta a las bases de la economía política de occidente, al respecto aclara Gow (2014):

To me, the most powerful chapter of this book is "The love of merchandise", which reminded me of the power of chapter 27 in volume 1 of Marx's Capital. Interested readers might choose to read hem together. I have the sense that they are about the same thing. Both chart the violent process of expropriation from a specific way of living in the world, and its replacement with an alienated consciousness of that loss, and the search for a synthetic understanding and a consequent way forward. But where Marx saw that process as an inevitable stage in the historical dialectic, Kopenawa sees it as an ongoing disaster that must be stopped. For Kopenawa, this is not progress, and he is admirably clear about the nature of Yanomami people's relationship to their world and the virtues of their relations with each other. Yanomami people have few things, and they are generous with them. White people want to have many things, and they want to keep the things they have, and get more. Kopenawa is mystified as to why this should be so. Reading "The love of merchandise", I began to think of Western critiques of environmentally destructive consumerism and why I had never before come across anything as powerful as Kopenawa's analysis (pp. 306-307).

Lo que está en juego en esta traducción nativa, en cuanto traducción cultural, es el contraste entre una economía fetiche de la mercancía y de la acumulación, cuya base antropológica es el hombre blanco colonizador, patrón y propietario caracterizando la cultura moderna occidental y una economía del don Yanomami, basada en una lógica del dar con generosidad, de la troca, no de la acumulación, y donde el máximo valor -no económico- cosmopolítico es la selva. De nuevo, la traducción nativa opera aquí entre inconmensurables culturales de modo crítico. La traducción cultural que implica cualquier traducción nativa no parte en estos casos de una búsqueda de reconocimiento, dejando de nuevo al blanco colonizador su legitimidad; al contrario, agencia como pensamiento autónomo, afirmando su dignidad y potencial deconstructor. Finalmente, los conceptos-acontecimentos urihi (tierra-selva) y la cosmopolítica: 
Para nós, a política é outra coisa. São as palavras de Omama e dos xapiri que ele nos deixou. São as palavras que escutamos no tempo dos sonhos e que preferimos, pois são nossas mesmo. Os brancos não sonham tão longe quanto nós. Dormem muito, mas só sonham com eles mesmos.

Para nosotros, la política es otra cosa. Son las palabras de Omama y de los xapiri que nos dejó. Son las palabras que escuchamos en el tiempo de los sueños y que preferimos, pues son nuestras. Los blancos no sueñan tan lejos como nosotros. Duermen mucho y solo sueñan con ellos mismos (Kopenawa y Albert, p. 390) (traducción propuesta).

Urihi (tierra-selva) a la base de la cosmopolítica traduce los límites antropocéntricos de la filosofia política moderna, que tornó el hombre -sujeto o individuo- en fundamento del pensamiento político; pues la cosmopolítica afirma las relaciones entre humanos y no- humanos para considerar a urihi (tierra-selva) como nuestra alteridad cosmológica (Valentim, 2015). He ahí el aprendizaje chamánico que donan los xapiri a través del sueño y hace de $A$ queda do céu un manifiesto cosmopolítico (Albert, 2015). Por tanto, a la filosofía política moderna y su humanismo universalista, que legitimó la existencia del Estado y la búsqueda de una ciudadanía universal o cosmopolitismo; la cosmopolítica responde afirmando la alteridad a urihi (tierra-selva), nuevas formas de socialidad entre humanos y no-humanos y estableciendo los límites cosmológicos al Estado como máquina antropocéntrica, genocida y ecocida. Crítica chamánica al Estado y al cosmopolitismo internacional, para afirmar la inminencia de la cosmopolítica como condición de vida tanto de humanos como de no-humanos. La fuerza de la cosmopolítica consiste así en ese proliferar de otros por el cual realiza su agenciamiento y al que intenta responder.

Esta serie de conceptos-acontecimientos además de confirmar la creatividad simbólica y política indígena, también apunta a lo que Albert (2002a) llamó una pacificação as avessas (ao branco) (pacificación a la inversa del blanco) (p. 10), recordando los límites de los mitos de los blancos y dando estos conceptos-acontecimientos desde su pensamiento cosmo-histórico (Albert, 2002a), para desestabilizar nuestras constelaciones conceptuales e interpelar nuestros modos de vivir. Una invitación generosa e ineludíble que indica el potencial crítico y creativo de la traducción nativa. 


\section{Nota final}

Ahora, unos apuntes respecto de la traducción nativa desde el intervalo histórico y geográfico de Guamán Poma y Kopenawa, con el objetivo de reivindicar la función po(é)tica y cosmopolítica de sus escrituras visuales y conceptuales. Las traducciones nativas actúan en el intersticio de constelaciones de imágenes y conceptos de culturas heterogéneas $\mathrm{y}$, a veces, inconmensurables.

En el caso de Guamán Poma de Ayala sus traducciones de imágenes actúan en el intervalo entre la multiplicidad de etnias andinas y el mundo español y europeo. Sin embargo, sus dibujos no intentan representar el mundo andino, al contrario, construyen un relato vivo y crítico de su historia antes del contacto, como después de los conflictos generados por el encuentro entre mundos. Aquí la traducción nativa compone un campo semiótico autónomo y micropolítico, pues las imágenes efectúan agenciamientos de denuncia, crítica y subversión de los órdenes coloniales. La vida de los dibujos los hace dislocarse entre: la codificación de los signos culturales andinos en los signos culturales no-andinos -españoles o europeos-, siempre con el objetivo estratégico de deslegitimar la conquista y las violencias producidas. Seguidamente, los dibujos comienzan a operar descodificaciones entre lo andino y lo no-andino, apuntando a las discontinuidades culturales, sus límites y sus fronteras, un movimiento semiótico crítico y micropolítico indicando la fuerza y potencial de los dibujos en las relaciones que se tejen con los otros dibujos. Finalmente, los dibujos efectúan trans-codificaciones eficaces para remover los fundamentos de la conquista y la colonización, al mismo tiempo que, usando sus mismos signos culturales los usa para su desacatamiento. En suma, las traducciones semióticas nativas en los dibujos de Guamán Poma indican la fuerza crítica, esto es, su capacidad de problematizar las relaciones entre signos culturales, sus funciones y efectos de poder; desdoblando su potencial performativo e indicando su fuerza para transgredir y transvalorar. Andinizar el signo o la imagen es, por tanto, tornarla campo de forcejeo y afirmación de la multiplicidad y autonomía de los pueblos andinos.

Paralelamente, la traducción nativa de Kopenawa (2015) en A queda do céu deja reverberando los conceptos bruma de metal (fumaça de metal), oro caníbal (ouro canibal), urihi (tierra-selva) y cosmopolítica. Estos conceptos consisten, al mismo tiempo, en acontecimientos tanto para los modos de pensar como para los modos de vivir de los blancos. Pues ellos no solo problematizan los mitos blancos; sino que ante 
los actos genocidas y ecocidas de los proyectos desarrollistas empresariales, militares e ilegales, dejan oír la voz de los interlocutores directos Yanomami, afirmándolos como agentes políticos y, aún más, constatando su sabiduría cosmopolítica. El potencial cosmopolítico de la traducción y conceptos nativos no tiene que ver tanto con una búsqueda de reconocimiento o legitimación, reproduciendo el acto colonizador; como con la autonomía de su pensamiento que acontece entre una multiplicidad humana y no-humana, capaz de afirmar la alteridad de urihi (tierra- selva) y de agenciar otros modos de socialidad. Esta es la palabra dada de los otros, es decir, estos otros humanos e no-humanos, que busca el chamán a través de la escucha y que reverbera en la sabiduría cosmopolítica de Kopenawa (2015).

Así, las imágenes-agenciamiento de Guamán Poma en la época colonial peruana y los conceptos-acontecimientos del chamán Yanomami Kopenawa en la contemporaneidad, reiteran la fuerza e inminencia conceptual, po(é)tica y cosmopolitíca de la traducción nativa, cuando piensa y actúa entre inconmensurables culturales para apuntar a una afirmación de la multiplicidad de modos de vida, responder a su autonomía y posibilitar el proliferar de otros como imagen e invitación inevitable del alma salvaje. Aquí dejamos reverberar la bella imagen del antropólogo Viveiros de Castro en la inconstancia del alma salvaje (2002) para referirse a ese constante devenir del indio en sus relaciones con otros, próximos y lejanos, al modo como construye socialidades con humanos y no-humanos, en fin a su pensamiento cosmopolítico afirmando siempre la multiplicidad de los otros, tornando tan viva a urihi y a la que cantan los chamanes Yanomami. 


\section{Referencias}

Adorno, R. (1981). On pictorial language and the typology of culture in a New World chronicle. Semiotica, 36(1-2), 51-106.

Albert, B. (1992). A fumaça do metal: história e representações do contato entre os Yanomami. Anuário Antropológico, 89, (pp. 151-189).

Albert, B. (2002a). Introdução: cosmologias do contato no norte-amazônico. En B. Albert y A. R. Ramos (Orgs.). Pacificando o branco: cosmologias do contato no norte-amazônico, (pp. 239-274). São Paulo: Editora UNESP.

Albert, B. (2002b). O ouro canibal e a queda do céu. Uma crítica xamânica da economia política da natureza. En B. Albert y A. R. Ramos (Orgs.). Pacificando o branco: cosmologias do contato no norte-amazônico, (pp. 239-274). São Paulo: Editora UNESP.

Betancourt, H., y López-Baralt, M. (1991). Ícono y conquista: Guaman Poma de Ayala. Hispanic Review, 59(3), p. 362.

Derrida, Jacques (1971). Firma, Acontecimiento, Contexto. Recuperado de: https:// www.ddooss.org/articulos/textos/derrida_firma.pdf

Gow, P. (2014). Listen to me, listen to me, listen to me, listen to me...: A brief commentary on The falling sky by Davi Kopenawa and Bruce Albert. Hau: Journal of Ethnographic Theory, 4(2).

Guamán. F. (1980 a). Nueva crónica y buen gobierno. John V. Murra y Rolena Adorno, eds.; traducciones del quechua por Jorge L. Urioste. 3 tomos. México D.F.: Siglo Veintiuno.

Guamán, F. (1980b). Nueva Corónica y Buen Gobierno (1615). En V. John y A. Rolena (Eds.). L. Jorge (Trad.). 3 tomos. México: Siglo XXI Editores.

Kelly, J. (2013). Resenha: KOPENAWA, D. \& ALBERT, B. La chute du ciel: paroles d'un chaman yanomami. R@U: Revista de Antropologia da UFSCar, São Carlos, v. 5 n. 1,

Kopenawa, D., y Albert, B. (2015). A queda do céu: palavras de um xamã yanomami. São Paulo: Companhia das Letras. 
Lizot, J. (1988). Los Yanomami, em los aborígenes de Venezuela, Etnología Contemporánea, Volumen III, Caracas: Fundación La Salle.

López-Baralt, M. (1988). La metáfora como traslatio: del código verbal al visual en la crónica ilustrada de Guaman Poma. Nueva Revista de Filología Hispánica, 36(1), p. $379-89$.

Quispe, R. (2004). Yo y el otro: identidad y alteridad en la Nueva Corónica y Buen Gobierno. Hispanic Issue, 119(2), 226-251.

Urioste, J. L. (1987). Los textos quechuas en la obra de Waman Puma. Recuperado de http://www.kb.dk/permalink/2006/poma/info/es/docs/urioste/1987/index.htm

Valentim, M. A. (2015). A sobrenatureza da catástrofe. Os mil nomes de Gaia: do antropoceno à idade da terra. Recuperado de https://osmilnomesdegaia.files. wordpress.com/2014/11/marco-antoniovalentim.pdf

Valentim, M. A. (s.f). A teoria e a queda do céu. ClimaCom, 2(4). Recuperado de http://climacom.mudancasclimaticas.net/?p=4120

Viveiros de Castro, E. (2012). A inconstância da alma selvagem. São Paulo: COSACNAIFY.

Viveiros de Castro, E. (2015). As metafísicas canibais. São Paulo: COSACNAIFY. 